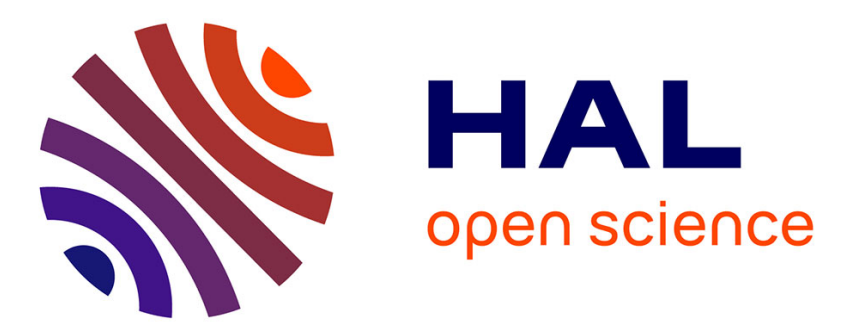

\title{
Influence of neighbouring woody treatments on Mediterranean oak development in an experimental plantation: better form but weaker growth
}

\author{
B. Prévosto, J. Gavinet, Y. Monnier, A. Corbani, C. Fernandez
}

\section{- To cite this version:}

B. Prévosto, J. Gavinet, Y. Monnier, A. Corbani, C. Fernandez. Influence of neighbouring woody treatments on Mediterranean oak development in an experimental plantation: better form but weaker growth. Forest Ecology and Management, 2016, 362, pp.89-98. 10.1016/j.foreco.2015.11.046 . hal01318384

\author{
HAL Id: hal-01318384 \\ https://hal.science/hal-01318384
}

Submitted on 19 May 2016

HAL is a multi-disciplinary open access archive for the deposit and dissemination of scientific research documents, whether they are published or not. The documents may come from teaching and research institutions in France or abroad, or from public or private research centers.
L'archive ouverte pluridisciplinaire HAL, est destinée au dépôt et à la diffusion de documents scientifiques de niveau recherche, publiés ou non, émanant des établissements d'enseignement et de recherche français ou étrangers, des laboratoires publics ou privés. 


\section{Influence of neighbouring woody treatments on Mediterranean oak development in an experimental plantation: better form but weaker growth}

Authors: Bernard PRÉVOSTO ${ }^{1}$, Jordane GAVINET ${ }^{1,3}$, Yogan MONNIER $^{2}$, Aude CORBANI ${ }^{1}$, Catherine FERNANDEZ ${ }^{3}$

1 - Institut national de recherche en sciences et technologies pour l'environnement et l'agriculture (Irstea), 3275 route de Cézanne, 13100 Aix-en-Provence, France

2- UMR AMAP, Cirad-Cnrs-Inra-Ird-Université Montpellier 2, 37/PS1, Bd de la Lironde

34398 Montpellier cedex 5

3 - Institut Méditerranéen de Biodiversité et d'Écologie marine et continentale (IMBE), Aix-Marseille Université, CNRS, IRD, Avignon Université, UMR 7263, 3 place Victor-Hugo, 13331 Marseille cedex 3, France

Corresponding author: Bernard PRÉVOSTO, e-mail: bernard.prevosto@ irstea.fr,

Telephone: +33442669925 
Author-produced version of the article published in Forest Ecology and Management, 2016, 362, 89-98

The original publication is available at http://sciencedirect.com

Doi: 10.1016/j.foreco.2015.11.046

\section{$\underline{\text { Abstract }}$}

Mixed plantations have been receiving increasing attention for their documented or supposed potential benefits over monospecific plantations. In particular, the use of neighbouring (or nurse) vegetation around target plants can enhance their performance through limitation of the competing herb layer, and can also improve their morphology.

Here we examine the benefits and drawbacks of using neighbour treatments on the response of target trees in open plantations. We set up an experimental plantation in southern France, in which two co-occurring target oak species (the evergreen Quercus ilex and the deciduous Quercus pubescens) were introduced in different neighbour treatments using a tree (Pinus halepensis) and a shrub species (the nitrogen-fixing Coronilla glauca). Oaks were planted with pine neighbours at two densities, with shrub neighbours, in a mixture of pines and shrubs or without neighbours. The ground vegetation was either regularly weeded or left to grow in order to detect any indirect facilitation interactions. Target oak responses (survival, growth, and morphology) were monitored over 7 years. Soil water content and light availability were also measured throughout the experiment.

We found competition to be the dominant process driving interactions between neighbours and target tree species. Growth was reduced for both species, but more in weeded than in unweeded treatments, showing an alleviation of competitive interactions by neighbours through limitation of herb layer development. However, in both ground vegetation treatments, growth was severely reduced with Coronilla shrubs. Survival was only significantly impaired for the less shade-tolerant $Q$. pubescens oak used in combination with shrubs. The negative influence of the neighbour treatments was mainly attributable to light interception, which was particularly high by shrub canopy. Soil moisture was also slightly reduced by shrub neighbours, but it remained high with pines in the unweeded treatment owing to a limited abundance of herbs. However, stem form was improved by the neighbour treatments: oaks developed narrower crowns and greater slenderness with neighbours, whereas oaks in the open showed a bushy morphology. These findings emphasize the need to clearly identify key objectives before implementing mixed plantations (e.g. maximising growth, survival, improving morphology, etc.) and to use active management to control potential undesirable effects of the neighbouring vegetation on target plants. 
Keywords: plant interactions, competition, facilitation, vegetation control, light availability, soil moisture

\section{$\underline{\text { Highlights }}$}

- Mediterranean oaks were planted with pines and shrubs as neighbours

- Shrubs were less favourable than pines to seedling growth and survival

- Growth was reduced with neighbour treatments, but form was improved

- Careful species selection and active management are needed in mixed plantations 
Author-produced version of the article published in Forest Ecology and Management, 2016, 362, 89-98

The original publication is available at http://sciencedirect.com

Doi: 10.1016/j.foreco.2015.11.046

\section{Introduction}

There is an increasing interest in promoting mixed rather than monospecific plantations. Potential benefits of mixed plantations have been reviewed by Kelty (2006): they come mainly from increased productivity due to complementary characteristics (e.g. growth rates, root depth, phenology, etc.) (Vilà et al., 2007; Paquette and Messier, 2011), higher plant diversity in mixed than in monospecific stands (Felton et al., 2010), improvement of stem quality in the early stage of stand development (Löf et al., 2014) and reduced risks of pest damage (Jactel and Brockerhoff, 2007). Some of these advantages have been well documented (e.g. reduction of pathogen outbreaks, Jactel and Brockerhoff, 2007) but other are still being debated (e.g. competition for water resource, Grossiord et al., 2014; Forrester, 2015). Besides these advantages, the use of mixtures can be a valuable tool for alleviating competitive interactions among target species and promote facilitation (Kelty, 2006). Interactions among plants are complex and can be both positive and negative: the net balance can vary in response to types of biotic and abiotic stress factors, species identity, time, site conditions (e.g. Callaway, 2007; Gomez-Aparicio, 2009), and according to the nature of the response variable selected (e.g. growth, survival, and morphological responses, Prévosto et $a l ., 2012)$. However, the role of facilitative interactions is reportedly more important in stressful conditions, such as Mediterranean environments (Castro et al. 2004; GómezAparicio et al. 2004; Padilla \& Pugnaire 2006; Gómez-Aparicio 2009), arguing for using accompanying plants that can nurse target plants in plantation operations. The use of nurse vegetation can directly improve the performance of the target trees (i.e. direct facilitation) by buffering the harsh climatic conditions prevailing in the open, such as excessive light radiation and extreme temperatures, and also by improving nutrition conditions, in particular when nitrogen-fixing plants are used (Gómez-Aparicio et al., 2004; Kelty, 2006). However, a major constraint in planting operations is the growth of a herb layer, which can limit tree seedling establishment (e.g. Rey Benayas et al. 2005; Prévosto et al., 2011b). Herbs are effective competitors for water due to canopy interception or direct uptake by roots. This is particularly detrimental to seedling survival and growth in water-limited environments (Ludwig et al., 2004; van der Waal et al., 2009), while competition for nutrients is more important in more mesic conditions (Pagès and Michalet, 2003). The use of neighbouring vegetation can slow the growth of the competitive herb layer by light reduction, and so benefit the planted seedlings through indirect facilitation sensu Levine (1999). Another possible negative consequence of trees being introduced in totally open conditions is poor stem form, 
Author-produced version of the article published in Forest Ecology and Management, 2016, 362, 89-98

The original publication is available at http://sciencedirect.com

Doi: 10.1016/j.foreco.2015.11.046

the development of thick lateral branches and the loss of apical dominance, clearly visible for some species (oak in particular), which can impair wood quality (Gauthier et al., 2013; Löf et $a l .$, 2014). Using neighbours around target trees can therefore improve their morphological response through space limitation and reduced light availability.

To test the potential benefits and drawbacks of using neighbour treatments on the response of target trees in open plantations, we devised an experiment in which two co-occurring target oak species (the evergreen Quercus ilex and the deciduous Quercus pubescens) were introduced in different neighbour treatments using a tree and a shrub species. As a tree neighbour we used Pinus halepensis, a pioneer light-demanding tree widespread in our area and forming stands that are naturally replaced by oaks in the course of succession (Quézel \& Barbero 1992). For a shrub, we selected Coronilla valentina subsp glauca, a common Nfixing species capable of rapid growth in open conditions. Shrubs, and in particular legume shrubs, have been successfully tested as nurse species in many planting operations or restoration experiments (Gómez-Aparicio et al. 2004; Kelty 2006; Forrester et al., 2006). Tree and shrub species, alone or combined, were tested with one of the two target oaks. To clearly determine whether the influence of the neighbour treatments on target species responses also operates through indirect interactions (i.e. by the intermediate of the ground vegetation), we manipulated the herb layer, which was either removed or left to grow.

In this experiment, we specifically tested the following three hypotheses:

i) Neighbours could positively influence survival and growth of target species particularly in the unweeded system due to limitation of herb competition (i.e. indirect facilitation).

ii) Stem form of target oaks would be improved by the neighbours.

iii) Responses of target plants would be species-specific and depend on density and lifeform (shrub/tree) of the neighbourhood, which influences main resource uptake (light and soil moisture here). 


\section{Materials and Methods}

\section{$\underline{\text { Study site }}$}

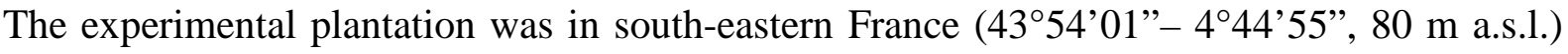
under a Mediterranean climate in a previously abandoned agricultural field. Mean annual temperature was $14{ }^{\circ} \mathrm{C}$. Mean annual rainfall was $689 \mathrm{~mm}$. The soil was homogeneous, with a loamy-sandy texture, a low stone load and a high depth $(>1 \mathrm{~m})$, and possessed a high waterholding capacity and fertility. In summer 2007, the pre-existing vegetation was mechanically removed and the ground was scarified to obtain a bare soil. Planting was carried out in February 2008 using 1-year-old plants grown from a local nursery in $1.2 \mathrm{~L}$ containers for the oak species and $0.56 \mathrm{~L}$ containers for the other species. As the target species, we used two late-successional oak species with contrasting leaf habit that co-occur in this region: the evergreen Quercus ilex L. and the winter deciduous Quercus pubescens Wild. For accompanying woody species, we chose the Aleppo pine tree Pinus halepensis Mill. and the $\mathrm{N}$-fixing shrub Coronilla valentina subsp. glauca. Just before planting, the oak seedlings were cut to a height of $10 \mathrm{~cm}$ and the shrubs to $15 \mathrm{~cm}$ to limit transplant shock.

\section{$\underline{\text { Treatments and experimental design }}$}

The two oak target species were planted using five neighbour treatments: pines at low density (Low pine), pines at high density (High pine), Coronilla shrubs (Coronilla), pines and Coronilla shrub in a mixture (Pine + cor) and a control with no neighbours (Control). Target species and neighbours were set up on a $2 \times 2.5 \mathrm{~m}$ plot: 12 oaks were regularly arrayed in 3 lines of 4 oaks per line. Oak seedlings were spaced at $0.5 \mathrm{~m}$ intervals in rows $0.5 \mathrm{~m}$ apart (Fig. 1). Neighbours were regularly arrayed using 20 pines for treatment (Low pine) so that each oak had 4 neighbours, and using 51 plants, either pines or shrubs or alternating pines and shrubs, for treatments (Coronilla), (High pine) and (Pine + cor) respectively ( 8 neighbours per oak). We set up a line of neighbours around the plot to limit edge effects, using 18 (Low pine) or 36 (High pine, Coronilla, Pine + cor) regularly spaced plants. In the control plot we also installed 18 oaks around the perimeter, but as in the other treatments, only the 12 central plants were used for subsequent measurements. 
A)

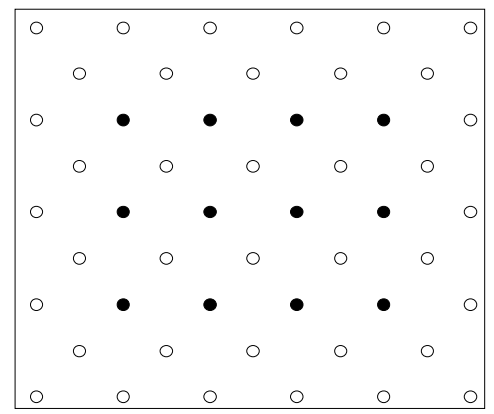

B)

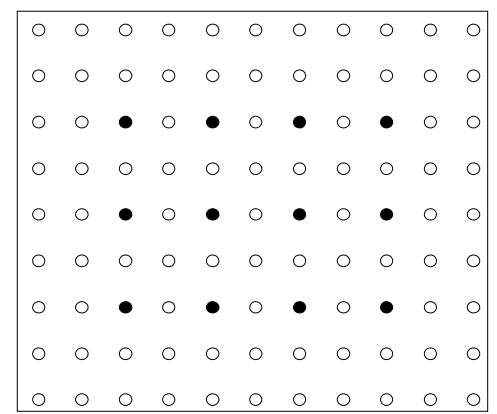

C)

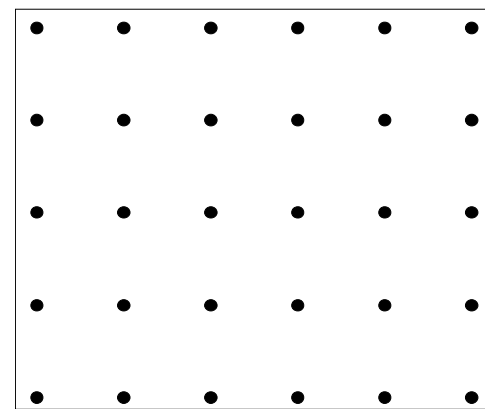

Figure 1. Experimental design of the plots. Black points indicate target species $(Q$. ilex or $Q$. pubescens) and white points indicate neighbours (pine or shrub). A) Pine neighbours at low density (Low pine). B) Pine at high density (High pine) or Coronilla shrub (Coronilla) or alternating pine and shrub (Pine + cor) neighbours. C) Control (Control).

Two treatments were applied for the control of the ground vegetation: herbs were either manually removed, twice a year in the two first years (spring and autumn) and then once a year up to 2012, or left to grow: vegetation that naturally developed comprised diverse weed species.

Treatments were replicated 4 times, giving a total of 80 plots $(2$ oak species $\times 5$ neighbour treatments $\times 2$ vegetation treatments $\times 4$ replicates). Plots were distributed in 8 blocks $(25 \mathrm{~m}$ $\times 12 \mathrm{~m}$ ), with each block containing the 2 target species and the 5 neighbour treatments randomly distributed within the block. Plots were separated by a distance of $2 \mathrm{~m}$ in each block, and a minimum buffer distance of $4 \mathrm{~m}$ was left between each block.

Blocks were randomly assigned to the weeding treatments, with half of the blocks being manually weeded (only the plots were weeded), while the other half were left unweeded.

The vegetation naturally developing between blocks was mechanically removed each year. The experiment was fenced (height $50 \mathrm{~cm}$ ) to prevent any damage by small herbivores (e.g. rabbits). However, during the experiment, we recorded some attacks by mice (Arvicola terrestris), and some oaks were stolen. A total of 21 target oaks were finally discarded from the study.

Pines were manually thinned in 2011, yielding final mean densities per plot of: 15.2 pines in the Low pine treatment $(\mathrm{SD}=1.97), 25.4$ pines in the High pine treatment $(\mathrm{SD}=2.10)$ and 26.1 pines in the Pine + cor treatment $(\mathrm{SD}=2.92)$. Coronilla shrubs were cut at the same period at height $40 \mathrm{~cm}$ and allowed to resprout. 
Author-produced version of the article published in Forest Ecology and Management, 2016, 362, 89-98

The original publication is available at http://sciencedirect.com

Doi: 10.1016/j.foreco.2015.11.046

\section{$\underline{\text { Plant and environmental measurements }}$}

Oak stems were tagged at about $2 \mathrm{~cm}$ above the ground. Stem diameter and height of all the oaks were measured at the end of each growing season, together with a subset of four neighbours per plot (only height was measured for shrubs).

On a subset of 4 oaks per plot, crown widths in two perpendicular directions were measured. A leader shoot was also marked in the top of the crown. At the end of each growing season, length and number of growth units produced per shoot were measured. Shoots that died or were damaged or lost their dominant status were replaced by another leader shoot.

Soil water content (SWC) was measured at $-60 \mathrm{~cm}$ at different time intervals in 2010 and 2014 in each plot with Quercus ilex seedlings. We used a TDR profile probe (PR2, Delta-T Devices) inserted in an access tube driven into the soil (total of 40 tubes). Three readings were taken at each location by rotating the probe through $120^{\circ}$. Photosynthetically active radiation (PAR, 400-700 $\mathrm{nm}$ ) was measured at three locations per plot using a linear ceptometer (Decagon Devices, Pullman, USA). Measurements were made above and below the plot canopy during clear days in June (11:00-14:00) of the three first years and then in 2014. Measurements were made in the upper part of the oaks (approximately $-20 \mathrm{~cm}$ below the apex). Light transmittance for each plot was then computed as the ratio of the mean PAR values measured above and below the canopy plot.

\section{$\underline{\text { Data analysis }}$}

We developed mixed models to separate the fixed effects (treatments, time, species) from the random effects (plots nested in blocks). Probability of oak survival as a function of neighbour treatment, vegetation treatment, time and species was modelled using a generalized linear mixed model with a binomial function (GLMM). Influences of the neighbour and vegetation treatments on seedling diameter, height and height/diameter ratio for both species were analysed using a linear mixed model (LMM). We also used an LMM for the light data.

Comparisons between treatments were analysed using Tukey post hoc tests. Prior to analysis we checked for ANOVA assumptions (normality, homogeneity of variances) and performed mathematical transformations if necessary to meet these conditions. 


\section{Results}

\section{$\underline{\text { Survival and growth }}$}

Probability of survival (Table 1) was significantly influenced by species identity, neighbour treatments and time, while vegetation treatment was not significant (Table 1). After 7 years, the survival rate was very high $(\geq 95 \%)$ for both oak species in the control and pine neighbour treatments (Fig. 1). By contrast, survival of $Q$. pubescens was severely impacted in treatments with Coronilla shrubs (alone or mixed with pines) with survival rates dropping below $50 \%$, whereas survival was still high for $Q$. ilex in the same treatments (>85\%).

Table 1. Results of the generalised linear mixed model for probability of survival (fixed effects, values for intercept not shown). "Neighbour" refers to the neighbour treatments and "Vegetation" to the vegetation treatments.

\begin{tabular}{lrrr} 
& Estimate & Std. Error & $p$ \\
\hline Species = Q. ilex & 1.96 & 0.71 & 0.006 \\
Neighbour = Coronilla & -7.43 & 1.84 & $<0.001$ \\
Neighbour = Pine + cor & -6.48 & 1.84 & $<0.001$ \\
Neighbour = Low pine & -3.20 & 1.90 & 0.10 \\
Neighbour = High pine & -1.25 & 2.07 & 0.55 \\
Vegetation = unweeded & -0.73 & 0.70 & 0.29 \\
Time (years) & -0.41 & 0.03 & $<0.001$ \\
\hline
\end{tabular}
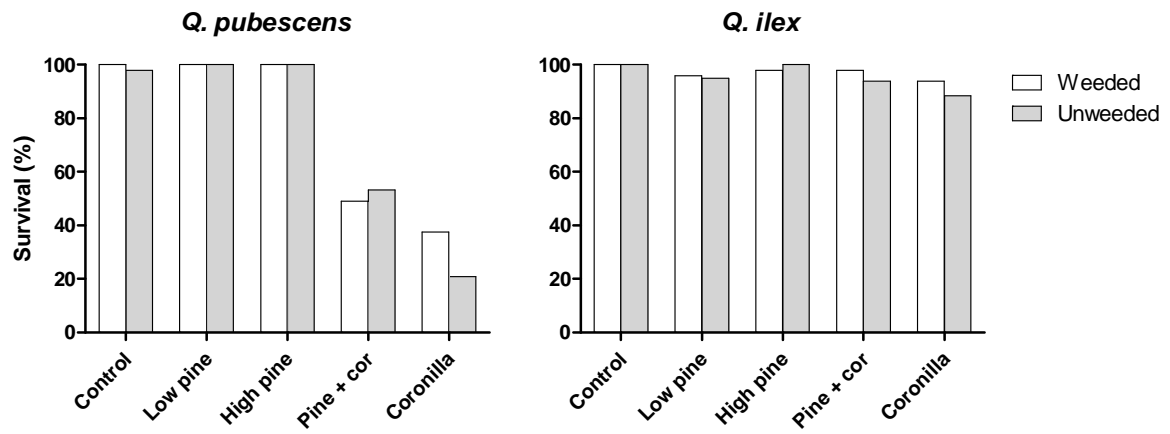

Figure 1. Percentage survival at the end of the experiment for the two oak species according to neighbour and vegetation treatments. 
Author-produced version of the article published in Forest Ecology and Management, 2016, 362, 89-98 The original publication is available at http://sciencedirect.com

Doi: 10.1016/j.foreco.2015.11.046

Diameter growth was significantly influenced by time, treatment and species and their interactions (See Table 2).

Table 2. Results of the linear mixed model for diameter and height. Significant $p$ values are shown in bold.

\begin{tabular}{llrlrl} 
& \multicolumn{4}{c}{ Diameter } & \multicolumn{3}{l}{ Height } \\
\cline { 2 - 7 } & Df & $F$ & $p$ & \multicolumn{1}{l}{$p$} \\
\hline Neighbour (N) & 4 & 4.51 & $\mathbf{0 . 0 0 2}$ & 5.8 & $<\mathbf{0 . 0 0 1}$ \\
Species $(\mathrm{S})$ & 1 & 20.09 & $<\mathbf{0 . 0 0 1}$ & 44.0 & $<\mathbf{0 . 0 0 1}$ \\
Time $(\mathrm{T})$ & 1 & 2518.60 & $<\mathbf{0 . 0 0 1}$ & 5335.1 & $<\mathbf{0 . 0 0 1}$ \\
Vegetation $(\mathrm{V})$ & 1 & 3.13 & 0.12 & 2.7 & 0.14 \\
$\mathrm{~N} \times \mathrm{S}$ & 4 & 0.27 & 0.89 & 0.8 & 0.50 \\
$\mathrm{~N} \times \mathrm{T}$ & 4 & 621.47 & $<\mathbf{0 . 0 0 1}$ & 67.7 & $<\mathbf{0 . 0 0 1}$ \\
$\mathrm{N} \times \mathrm{V}$ & 4 & 3.51 & $\mathbf{0 . 0 1}$ & 3.1 & $\mathbf{0 . 0 2}$ \\
$\mathrm{S} \times \mathrm{T}$ & 1 & 13.00 & $<\mathbf{0 . 0 0 1}$ & 33.3 & $<\mathbf{0 . 0 0 1}$ \\
$\mathrm{S} \times \mathrm{V}$ & 1 & 0.62 & 0.43 & 1.8 & 0.18 \\
$\mathrm{~T} \times \mathrm{V}$ & 1 & 28.38 & $<\mathbf{0 . 0 0 1}$ & 0.1 & 0.81 \\
$\mathrm{~N} \times \mathrm{S} \times \mathrm{T}$ & 4 & 42.58 & $<\mathbf{0 . 0 0 1}$ & 2.6 & $\mathbf{0 . 0 4}$ \\
$\mathrm{N} \times \mathrm{S} \times \mathrm{V}$ & 4 & 1.20 & 0.32 & 0.3 & 0.88 \\
$\mathrm{~N} \times \mathrm{T} \times \mathrm{V}$ & 4 & 4.35 & $\mathbf{0 . 0 0 2}$ & 1.4 & 0.22 \\
$\mathrm{~S} \times \mathrm{T} \times \mathrm{V}$ & 1 & 6.21 & $\mathbf{0 . 0 1 3}$ & 0.0 & 0.97 \\
\hline & & & & & \\
\hline
\end{tabular}

Change in growth diameter over time according to treatment is shown in Figure 2. For both species, and whatever the vegetation treatment, the growth in the control treatment was always the highest over time. The lowest growth was recorded in the treatment mixing pine trees and Coronilla shrubs. In the treatment with Coronilla only, the growth was especially low in the three first years, and then accelerated in subsequent years when surviving oak trees started to outcompete the neighbouring shrubs. Differences in diameter growth among neighbour treatments were more pronounced in the weeded than in the unweeded system. At the end of the experiment, diameters were higher in the weeded control than in the unweeded control for both $Q$. pubescens (respectively $39.6 \mathrm{~cm}$ and $34.7 \mathrm{~cm}, p<0.05$ ) and $Q$. ilex (35.2 $\mathrm{cm}$ and $23.9 \mathrm{~cm}, p<0.01)$. It was noteworthy that growth limitation in the unweeded control treatment was particularly marked up to the third year. After this period, the oaks were able to escape competition by herbs and showed an accelerated growth. Similar results were 
Author-produced version of the article published in Forest Ecology and Management, 2016, 362, 89-98 The original publication is available at http://sciencedirect.com Doi: 10.1016/j.foreco.2015.11.046

recorded for the Low and High pine treatments, although they were not significant for $Q$. pubescens in the Low pine treatment. However, no differences were noted in the Pines + cor and the Coronilla treatments between weeded and unweeded treatments.
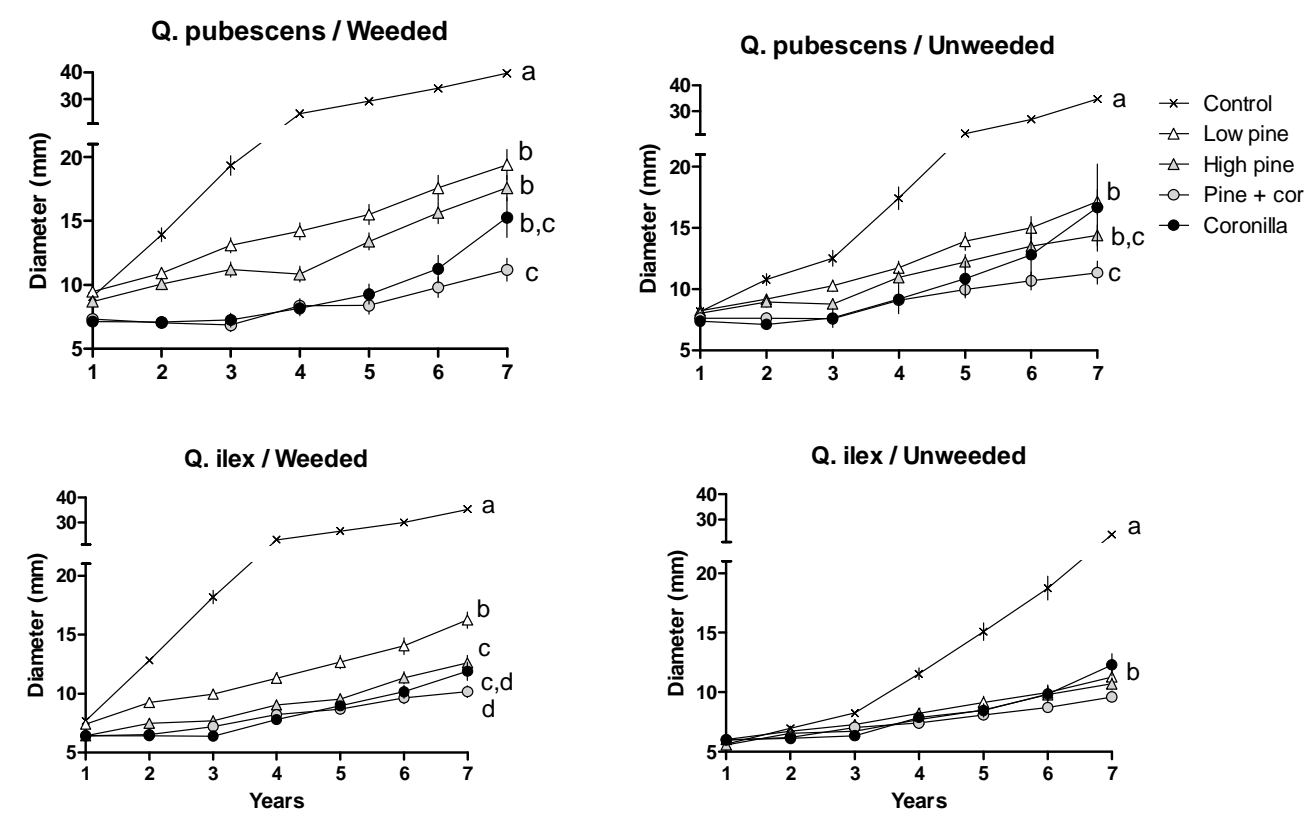

Figure 2. Changes in stem diameter (mean $\pm S E$ ) over time for the two oak species according to neighbour and vegetation treatments. Different letters indicate significant changes for the last date.

Height growth showed a pattern similar to diameter growth (Fig. 3, Table 2). It was always higher in the control than in the other neighbour treatments for both species and vegetation treatments, while the lowest values were recorded in the High pine and Pine + cor treatments. Height was also greater at the end of the study period in the weeded than in the unweeded plots for both species in the Control and Low pine treatments, except for $Q$. pubescens in the Low pine treatment $($ weeded $=137 \mathrm{~cm}$, unweeded $=117 \mathrm{~cm}, p=0.1$ ). By contrast, height was not influenced by the vegetation treatment in other neighbourhood conditions. The acceleration of growth in the Coronilla treatment noted for diameter after 3 years was also observed for height and was even more pronounced. For diameter, differences among neighbour treatments were also less marked in the unweeded than in the weeded conditions. 
Author-produced version of the article published in Forest Ecology and Management, 2016, 362, 89-98
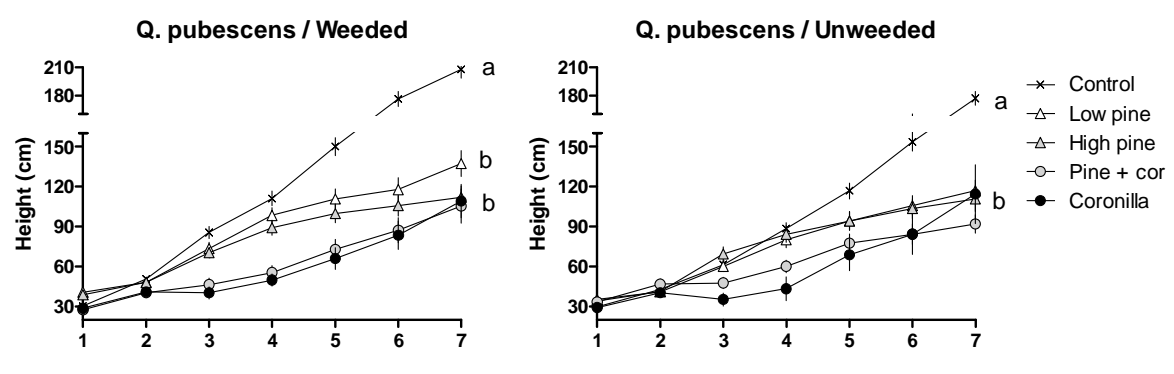

Q. ilex / Weeded
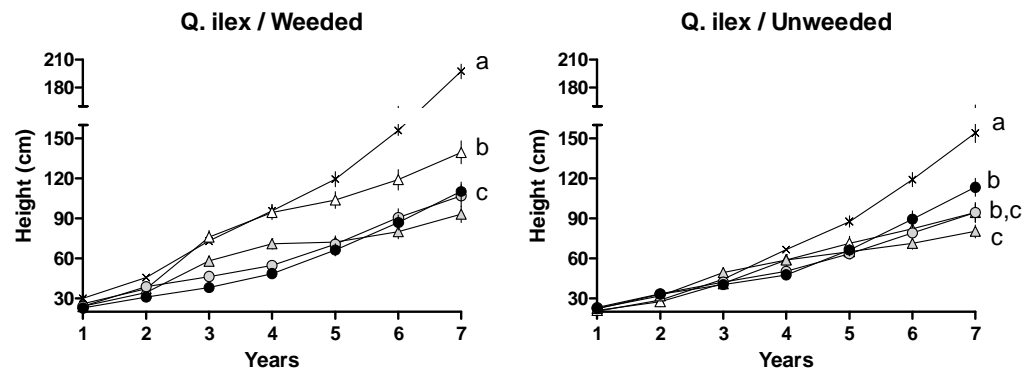

Figure 3. Changes in height (mean $\pm \mathrm{SE}$ ) over time for the two oak species according to neighbour and vegetation treatments. Different letters indicate significant changes for the last date.

We also established changes in neighbour species height according to the different treatments (Fig. 4). Coronilla cover rapidly developed and after one year reached a mean height of $90 \mathrm{~cm}$ (Coronilla and Pine + cor treatments together), whereas mean pine height was only $53 \mathrm{~cm}$. In the following years some shrubs died, and in the last year, the cover values for Coronilla were respectively $44 \%$ and $65 \%$ in the treatments with Coronilla only or mixed with pines $(F=9.11, p=0.005)$. Pines developed regularly with time, but height growth was the highest in the low pine treatment and the lowest in Pine + cor treatment due to shrub competition, which was particularly pronounced in the first 3 years after planting.

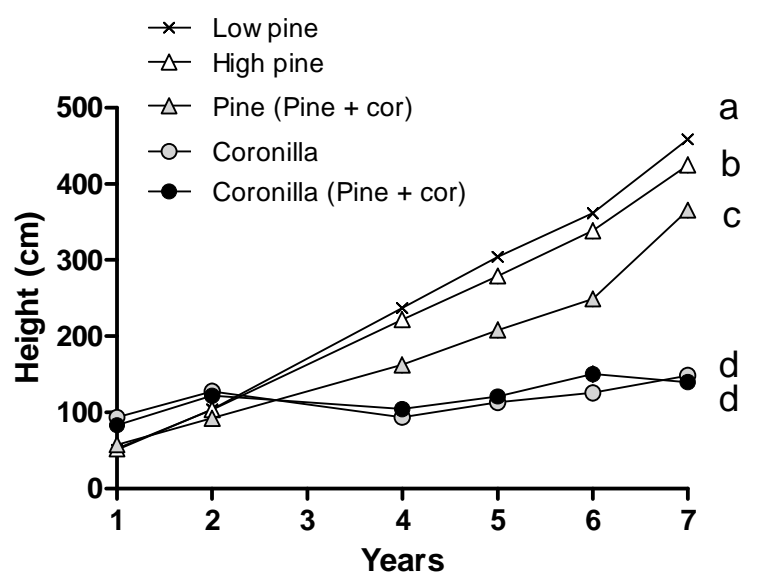

Figure 4. Changes in height (mean $\pm \mathrm{SE}$ ) of the neighbouring species over time for the different treatments. Different letters indicate significant changes for the last date (tests done separately for pines and Coronilla shrubs). 


\section{Morphological responses}

Height/diameter ratio and crown width were used as morphological responses of the target seedlings to the different treatments. The effects are presented Table 3.

These two descriptors were largely influenced by time and species identity, whereas neighbour treatments were only significant for the height/diameter ratio and no influence of the vegetation treatment was detected, except in interaction with the other factors (Table 3). Height/diameter values globally increased with time. They were minimal at the end of the study period in the control treatment whatever the species and the vegetation treatment (Fig. 5). By contrast, maximal slenderness (tall, thin seedlings) was noted in the treatments with Coronilla shrubs. Intermediate situations occurred with pine treatments.

Table 3. Results of the linear mixed model for height/diameter ratio and crown diameter. Significant $p$ values are shown in bold.

\begin{tabular}{|c|c|c|c|c|c|}
\hline & \multicolumn{3}{|c|}{$\mathrm{H} / \mathrm{D}$} & \multicolumn{2}{|c|}{ Crown diameter } \\
\hline & Df & $F$ & $p$ & $F$ & $p$ \\
\hline Neighbour (N) & 4 & 8.94 & $<0.001$ & 1.36 & 0.25 \\
\hline Species (S) & 1 & 6.11 & 0.01 & 74.71 & $<0.001$ \\
\hline Time $(\mathrm{T})$ & 1 & 1982.22 & $<0.001$ & 1414.25 & $<0.001$ \\
\hline Vegetation (V) & 1 & 0.53 & 0.48 & 3.96 & 0.07 \\
\hline $\mathrm{N} \times \mathrm{S}$ & 4 & 1.60 & 0.18 & 0.79 & 0.53 \\
\hline $\mathrm{N} \times \mathrm{T}$ & 4 & 17.03 & $<0.001$ & 30.05 & $<0.001$ \\
\hline $\mathrm{N} \times \mathrm{V}$ & 4 & 0.81 & 0.52 & 7.09 & $<0.001$ \\
\hline $\mathrm{S} \times \mathrm{T}$ & 1 & 42.22 & $<0.001$ & 12.6 & $<0.001$ \\
\hline $\mathrm{S} \times \mathrm{V}$ & 1 & 0.01 & 0.92 & 0.16 & 0.69 \\
\hline $\mathrm{T} \times \mathrm{V}$ & 1 & 0.01 & 0.91 & 15.13 & $<0.001$ \\
\hline $\mathrm{N} \times \mathrm{S} \times \mathrm{T}$ & 4 & 6.99 & $<0.001$ & 6.59 & $<0.001$ \\
\hline $\mathrm{N} \times \mathrm{S} \times \mathrm{V}$ & 4 & 0.92 & 0.46 & 2.46 & 0.06 \\
\hline $\mathrm{N} \times \mathrm{T} \times \mathrm{V}$ & 4 & 1.73 & 0.14 & 6.15 & $<0.001$ \\
\hline $\mathrm{S} \times \mathrm{T} \times \mathrm{V}$ & 1 & 0.40 & 0.52 & 4.33 & 0.04 \\
\hline
\end{tabular}


Author-produced version of the article published in Forest Ecology and Management, 2016, 362, 89-98 The original publication is available at http://sciencedirect.com

Doi: 10.1016/j.foreco.2015.11.046

Q. pubescens / Weeded

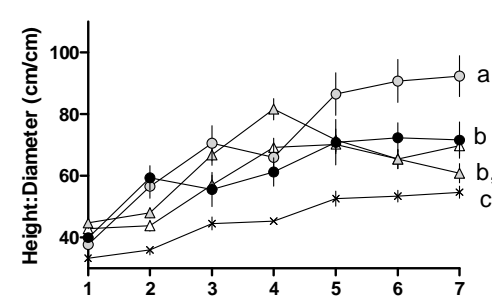

Q. ilex / Weeded

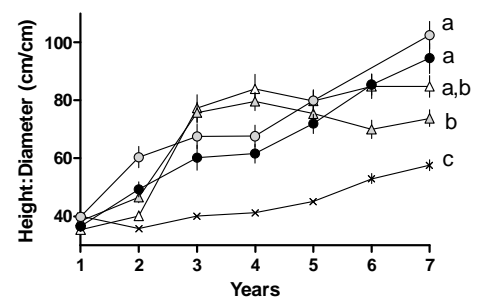

Q. pubescens / Unweeded

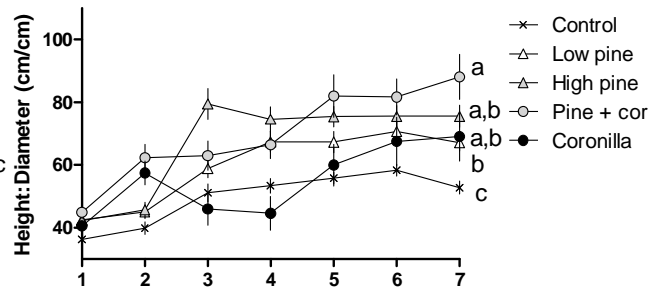

Q. ilex / Unweeded

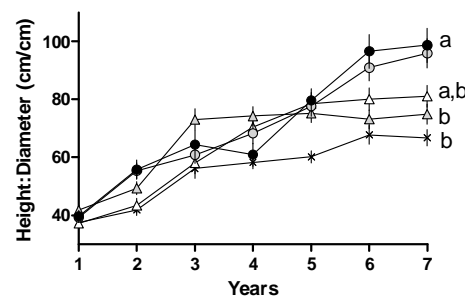

Figure 5. Changes in height/diameter ratio (mean \pm SE) over time for the two oak species according to the different treatments. Different letters indicate significant changes for the last date.

Changes in crown width with time according to the different treatments (Fig. 6) showed a pattern similar to stem diameter (see Fig. 1). Oak seedlings growing without neighbours or with pine neighbours at low density exhibited larger crowns than seedlings in the other treatments, in particular in the treatments with Coronilla shrubs.
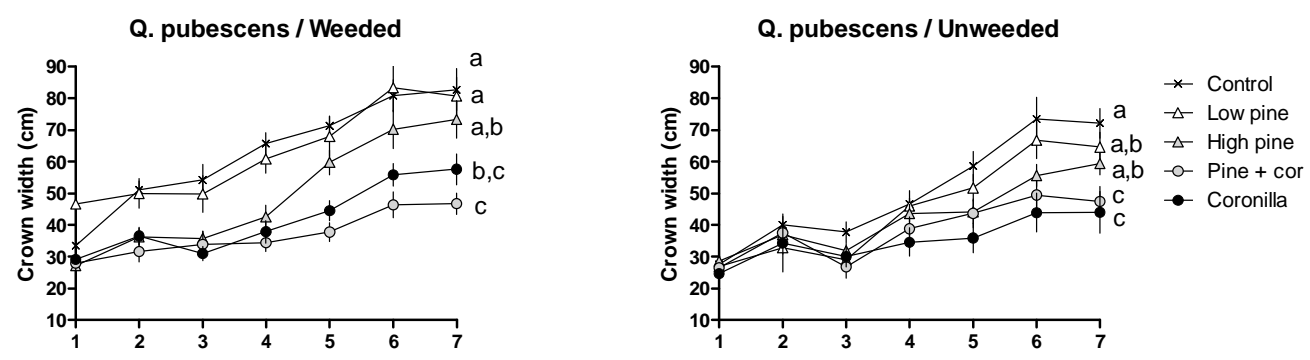

Q. ilex / Weeded
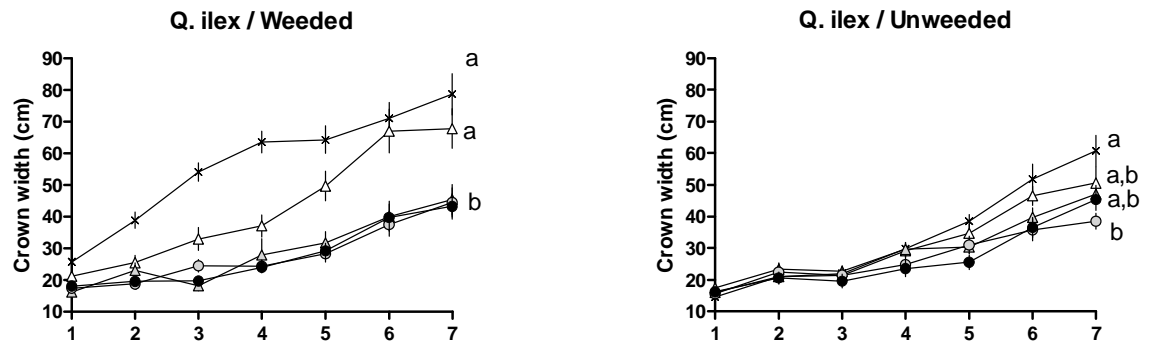

Figure 6. Changes in crown width (mean $\pm \mathrm{SE}$ ) over time for the two oak species according to the different treatments. Different letters indicate significant changes for the last date. 
Author-produced version of the article published in Forest Ecology and Management, 2016, 362, 89-98

The original publication is available at http://sciencedirect.com

Doi: 10.1016/j.foreco.2015.11.046

The mean number of growth units produced yearly per shoot over the six last years did not change according to the oak species ( $Q$. pubescens $1.54, Q$. ilex $1.55, p=0.84$ ) or ground vegetation treatments (weeded 1.57, unweeded 1.52, $p=0.16$ ). However, a significant effect of the neighbour treatments was observed: the number of growth units produced per shoot was largely higher in the control than in the other treatments for both $Q$. pubescens (respectively 2.02 and $1.42, p<0.001$ ) and $Q$. ilex (respectively 1.98 and $1.44, p<0.001$ ). As a result, mean shoot length was significantly greater in the control than in the neighbour treatments $(Q$. pubescens $30.64 \mathrm{~cm}$ vs. $19.02 \mathrm{~cm} p<0.001$; Q. ilex $27.58 \mathrm{~cm}$ vs. $18.48 \mathrm{~cm}$ $p<0.001)$.

\section{Light availability, soil moisture and water stress}

Light transmittance (below/above) was reduced in all the treatments with neighbours (Fig. 7), but the decrease was especially marked in treatments with Coronilla shrubs: it was approximately halved in the first year (respectively 0.46 and 0.55 in Coronilla and Pine + cor treatments) and fell below 5\% the second year. Reduction of light transmittance with time was more gradual in the pine treatments, but in the last year light transmittance was below $10 \%$ (respectively $9.3 \%$ and $7.7 \%$ in Low pine and High pine treatments). It is noteworthy that light availability peaked at $32 \%$ in the last year in the Coronilla treatment. This increase was explained by an opening in the shrub layer due to some mortality, allowing a part of the oak seedlings to overtop the neighbouring shrubs.

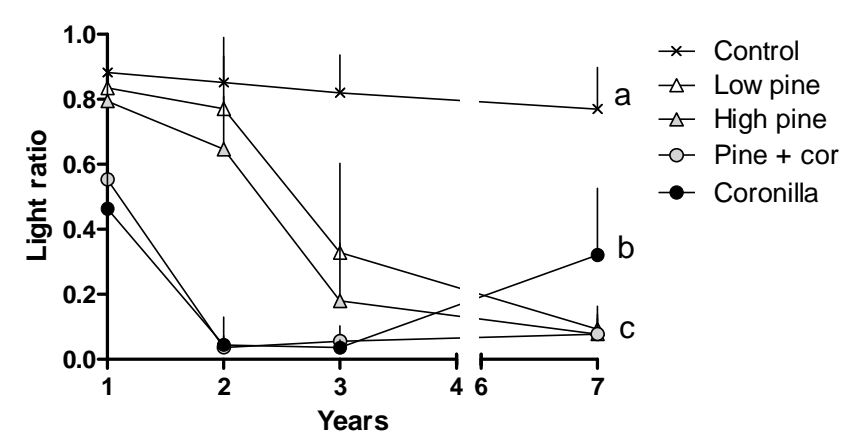

Figure 7. Changes in light ratio (below/above, mean $+\mathrm{SD}$ ) according to the neighbour treatments for different years. Different letters indicate significant changes among the treatments for the last year. 
Author-produced version of the article published in Forest Ecology and Management, 2016, 362, 89-98

The original publication is available at http://sciencedirect.com

Doi: 10.1016/j.foreco.2015.11.046

Changes in soil water content (SWC) are shown Fig. 8. In the third year in the weeded treatments, SWC was significantly influenced by the neighbour treatments $(F=17.61$, $p<0.001)$ and was lower in the Pine + cor and Coronilla treatments (respectively 24.3 and $26.2 \%$ over the growing season) than in the other treatments (between $28.8 \%$ and $29.7 \%$ ). In the unweeded treatment, influence of the neighbour treatments was also significant $(F=$ 22.32, $p<0.001)$, but SWC was maximal in the Low pine treatment $(30.8 \%$ over the third year) and minimal in the Coronilla treatment $(24.3 \%)$.

In the last year of the experiment, the same patterns were observed, but differences among treatments were largely reduced, both in the weeded ( $\min$ Pine + cor $=22.4 \%$, max Low pine $=25.7 \%$ for the whole season) and unweeded systems ( $\min$ Coronilla $=22.2 \%$, max Low Pine $=26.1 \%)$.
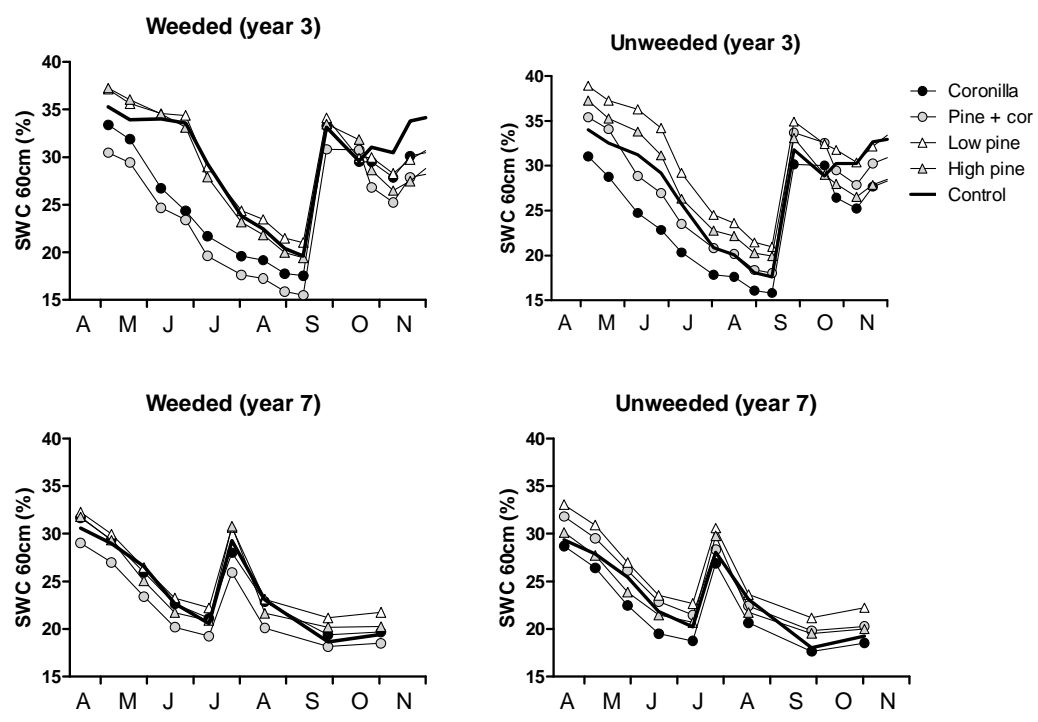

Figure 8. Changes in mean soil water content (depth $-60 \mathrm{~cm}$ ) with time (months: April to November) according to the neighbour treatments in the weeded and unweeded treatments for years 3 and 7.

Measurements of predawn leaf water potentials were made in the first and second growing seasons for both oak species and vegetation treatments, but only for three contrasting neighbour treatments (Fig. 9). Except for the first year in the unweeded treatment, potentials were always lowest in treatment with Coronilla shrubs. This result is in line with the reduced survival and growth rates also recorded in this treatment. 

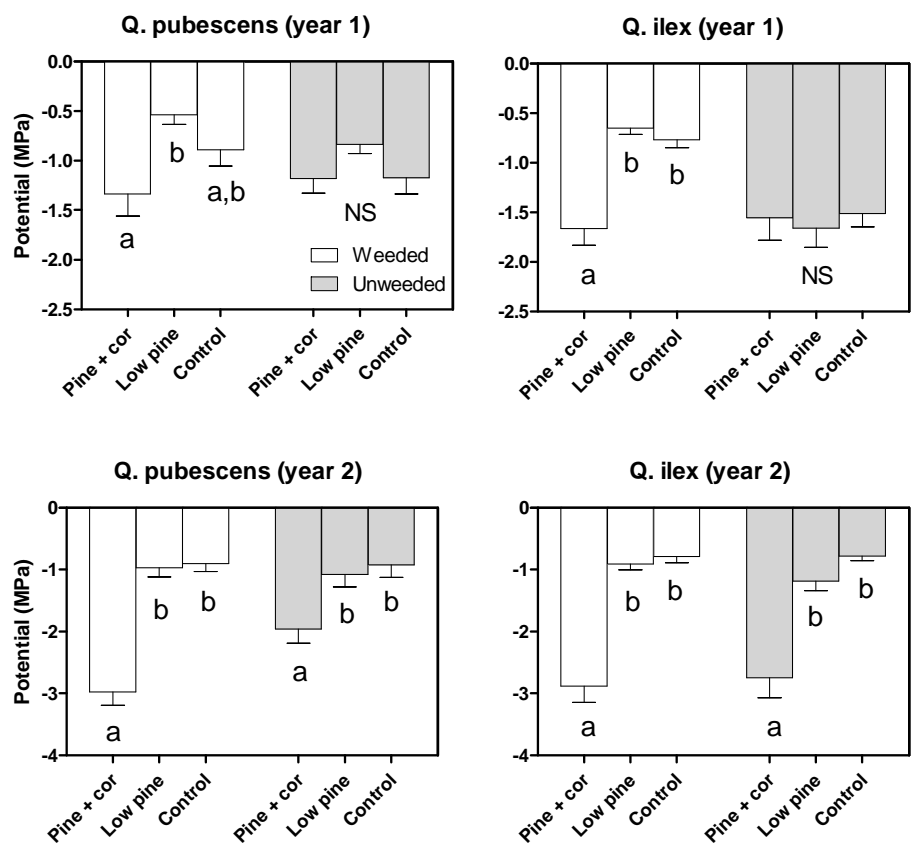

Figure 9. Predawn leaf water potentials measured during summer in two consecutive years according to neighbour treatments. Different letters indicate significant differences between treatments.

\section{Discussion}

\section{$\underline{\text { Influence of neighbours on competitive interactions and resources }}$}

Our first hypothesis was not supported: competition was found to be the dominant process driving interactions between neighbour and target tree species. This finding confirmed our first results based on a three-year study period (Prévosto et al., 2012). One effect of competition was a decreased survival noted for $Q$. pubescens in neighbour treatments with Coronilla shrubs used alone or mixed with pines. A second consequence was a reduced growth in diameter and height growth for both oak species and for all the neighbour treatments compared with the control treatment. This impact of competition can be explained by the rapid development of the neighbour vegetation and its efficient resource uptake. Light, commonly considered as a major limiting factor for forest vegetation development (e.g. Barbier et al., 2008), was the resource most rapidly and strongly reduced by the presence of a woody neighbourhood. This was particularly noticeable for Coronilla shrubs, which established a closed cover after only two years. As a result, light was dramatically reduced in the treatments with Coronilla shrubs in which light transmittance was below 5\%, whereas it remained above $60 \%$ in the other treatments due to the higher crown transparency of pine 
Author-produced version of the article published in Forest Ecology and Management, 2016, 362, 89-98

The original publication is available at http://sciencedirect.com

Doi: 10.1016/j.foreco.2015.11.046

trees. Light reduction was accompanied by a decrease in soil moisture availability, particularly marked in the treatments with Coronilla shrubs in the first years. This finding could again be explained by the larger canopy cover development of shrubs compared with pines, leading to higher rainfall interception and higher transpiration. This combination of light and soil moisture reduction explains the relatively low survival of $Q$. pubescens in these conditions. This species was in fact less shade- and drought-tolerant than $Q$. ilex, confirming previous results also obtained in field conditions (Prévosto et al., 2011a,b). However, the negative influence of the shrubs on oak survival and growth was limited in time. After four years, oaks overtopped the shrubs or took advantage of gaps formed in the Coronilla cover. This effect was more pronounced for $Q$. pubescens because of its higher growth capacity compared with $Q$. ilex, and was also less marked in the mixture of shrubs and pines, as pine trees developed more quickly once they escaped from the shrub competition, and then formed an overstorey layer. These results therefore support our third hypothesis: the oak responses were largely linked to species identity (mostly to their shade tolerance and growth ability, as also found by Liancourt et al., 2005) and to the capacity of the neighbourhood to take up resources, in particular light.

Unexpectedly, we did not detect any significant indirect facilitation (sensu Levine 1999) in this study i.e. the negative effect of the neighbourhood on resources (light and water here) was not outbalanced by an indirect positive effect due to herb limitation. Competition by the herb layer is a major factor affecting tree seedling development in water-stressed systems (e.g. Ludwig et al. 2004, Cuesta et al., 2010), and suppression or limitation of the ground vegetation by nurse plants (trees or shrubs) has often been reported to lead to facilitation in both temperate and Mediterranean conditions (Pages and Michalet, 2003; Maestre et al., 2004; Cuesta et al., 2010). In the unweeded treatment, herb abundance decreased sharply with light availability from the control to the pine treatments, and was lowest in the treatments with Coronilla shrubs (Prévosto et al., 2012). However, despite this herb limitation, target oaks always performed better in the control treatment than in the other neighbour treatments in the unweeded conditions. We detected an alleviation of the competitive interactions only in the unweeded treatment compared with the weeded treatments, particularly marked for diameter growth. For instance, in the unweeded Low pine treatment, the target oaks benefited from a higher light availability than in the other pine treatments, but this advantage was partially offset by the growth of a more abundant herb layer. As a result, the magnitude of the growth response among neighbour treatments was reduced in the unweeded compared with the weeded treatment. 
Author-produced version of the article published in Forest Ecology and Management, 2016, 362, 89-98

The original publication is available at http://sciencedirect.com

Doi: 10.1016/j.foreco.2015.11.046

These results are in line with those of Jensen et al. (2011) who tested the effects of shrubs and herbaceous vegetation on $Q$. robur seedlings in a three-year experiment. They showed that shrubs indirectly facilitated oak growth, but only transiently, and that the net interaction outcome shifted to competition at the end of the experiment.

\section{Influence on morphology}

We used height/diameter ratio and crown width as two basic descriptors of plant morphology in this study. We showed that slenderness was increased and crown width reduced in the treatments with neighbours compared with the control, thus supporting our second hypothesis: "stem form was improved by the neighbour treatments". By contrast, oaks growing in open conditions tended to develop larger crowns, numerous shoots and to lose apical dominance, resulting in a bushy morphology (Mediavilla and Escudero, 2010). These results were expected and illustrate the "shade avoidance syndrome" (Grime 2001) due to reduction of light availability and also modifications of light quality. Light reduction can promote higher allocation of resources to stem elongation than to lateral branches (Takenaka, 2000). Besides, the presence of neighbours around oak seedlings also formed a physical barrier to lateral crown extension, explaining reduced crown width in these conditions. Amelioration of the stem form was also noted by Prévosto and Balandier (2007) in an experiment in which target beech seedlings were introduced simultaneously with Scots pine and silver birch neighbours. Similarly, Löf et al. (2014) reported thinner branches in the crown of some target species planted with silver birch or hybrid larch neighbours. Similarly, Saha et al (2012) reported that target oaks quality benefitted from the presence of trainer trees in group plantings and Medhurst et al (2003) found a loss of apical dominance and thicker branches of Acacia melanoxylon target trees in the absence of Pinus radiata nurses. It should be noted that the results obtained in this study mostly apply to an establishment phase and that a longer period of study is needed to determine whether the influence of treatments on tree form could persist.

\section{Implications for management}

There is a growing interest in forest managers establishing mixed rather than monospecific plantations, in particular to develop facilitative interactions favouring survival and growth, and to increase wood quality. However, in the light of the results obtained in this experiment, 
Author-produced version of the article published in Forest Ecology and Management, 2016, 362, 89-98

The original publication is available at http://sciencedirect.com

Doi: 10.1016/j.foreco.2015.11.046

mixed plantations also face serious limitations and call for adaptive operations. We used a fast-growing nitrogen-fixing shrub species (Coronilla) because we expected a benefit in terms of growth through amelioration of soil fertility and efficient control of the competitive ground vegetation. However, the shrub developed too fast, competing with the target oaks and impairing their development. Competition was particularly marked for the deciduous $Q$. pubescens, which is more light-demanding than the evergreen $Q$. ilex. Competition was also observed with the neighbouring pines, although it was much less intense and differed in time. Active management is thus needed to curb the negative influence of the neighbourhood on seedling development (e.g. thinning at regular time intervals), although this strategy can sometimes be unrealistic in real forest management for economic reasons. Another way would be to use specific spatial arrangements during the plantation operation (e.g. introducing species in blocks or in multiple rows) or different time sequences (e.g. deferring the introduction of the target species) (see Kelty, 2006). Mixed plantations are thus quite complex to set up and first require clear prioritisation of the objectives to be reached: maximising the production of the whole stand, focusing on the survival of the target plants, favouring their growth, improving their stem quality, etc. These choices must be made to select the most appropriate attributes of the target and neighbour plants. Among the criteria to be selected, life-form alone is not sufficient; the capacity of the species to take up resources is also of prime importance.

\section{Acknowledgments}

This study was supported by the French Region Provence-Alpes-Côte d'Azur and the French Minister of Ecology (MEDDE-DEB).

The authors are especially grateful to R. Estève, JM Lopez, M. Audouard, F. Guerra, C. Travaglini, A. N'Daye, and W. Martin for data collection. The authors also thank C. Ripert for his collaboration. 


\section{References}

Callaway, R.M., 2007. Positive interactions and interdependence in plant communities. Springer, Dordrecht.

Castro, J., Zamora, R., Hódar, J.A., Gómez-Aparicio, L., 2004. Benefits of using shrubs as nurse plants for reforestation in Mediterranean mountains: A 4-year study. Restor. Ecol., 12, $352-358$.

Cuesta, B., Villar-Salvador, P., Puértolas, J., Rey Benayas, J.M., Michalet, R., 2010. Facilitation of Quercus ilex in Mediterranean shrubland is explained by both direct and indirect interactions mediated by herbs. J. Ecol. 98, 687-696.

Felton, A., Lindbladh, M., Brunet, J., Fritz, O., 2010. Replacing coniferous monocultures with mixed-species production stands: An assessment of the potential benefits for forest biodiversity in northern Europe. For. Ecol. Manage. 260, 939-947.

Forrester, D.I., Bauhus, J., Cowie, A.L., Vanclay, J.K., 2006. Mixed-species plantations of Eucalyptus with nitrogen fixing trees: A review. For. Ecol. Manage. 233, 211-230.

Forrester, D.I., 2015. Transpiration and water-use efficiency in mixed-species forests versus monocultures: Effects of tree size, stand density and season. Tree Physiol. 35, 289-304.

Gauthier, M., Zellers, K.E., Löf, M., Jacobs, D.F., 2013. Inter- and intra-specific competitiveness of plantation-grown American chesnut (Castanea dentata). For. Ecol. Manage. 291, 289-299.

Gómez-Aparicio, L., Zamora, R., Gómez, J.M., Hódar, J.A., Castro, J., Baraza, E., 2004. Applying plant facilitation to forest restoration: a meta-analysis of the use of shrubs as nurse plants. Ecol. Appl.14, 1128-1138.

Gómez-Aparicio, L., 2009. The role of plant interactions in the restoration of degraded ecosystems: a meta-analysis across life-forms and ecosystems. J. Ecol. 97, 1202-1214. 
Author-produced version of the article published in Forest Ecology and Management, 2016, 362, 89-98

The original publication is available at http://sciencedirect.com

Doi: 10.1016/j.foreco.2015.11.046

Grime, J.P., 2001. Plant Strategies and Vegetation Processes and Ecosystems Properties. 2nd edn. John Wiley \& Sons, Ltd, Chichester, UK.

Grossiord, C., Granier, A., Ratcliffe, S., Bouriaud, O., Bruelheide, H., Checko, E., Forrester, D.I., Dawud, S.M., Finer, L., Pollastrini, M., Scherer-Lorenzen, M., Valladares, F., Bonal, M., Gessler, A., 2014. Tree diversity does not always improve resistance of forest ecosystems to drought. PNAS 111, 14812-14815

Jactel, H., Brockerhoff, E.G., 2007. Tree diversity reduces herbivory by forest insects. Ecol. Letters 10, 835-848.

Jensen, A.M., Löf, M., Gardiner, E.S., 2011. Effects of above- and below-ground competition from shrubs on photosynthesis, transpiration and growth in Quercus robur L. Environ. Exp. Bot. 71, 367-375.

Kelty, M.J., 2006. The role of species mixture in plantation forestry. For. Ecol. Manage. 233, 195-204.

Levine, J.M., 1999. Indirect facilitation: evidence and predictions from a riparian community. Ecology, 80, 1762-1769.

Liancourt, P., Callaway, R.M., Michalet, R., 2005. Stress Tolerance and CompetitiveResponse Ability Determine the Outcome of Biotic Interactions. Ecology 86, 1611-1618.

Löf, M., Bolte, A., Jacobs, D.F., Jensen A.M., 2014. Nurse trees as a forest restoration tool for mixed plantations: effects on competing vegetation and performance in target tree species. Restor. Ecol. 22, 758-765.

Ludwig, F., Dawson, T.E., Prins, H.H.T., Berendse, F., Kroon, H., 2004. Below-ground competition between trees and grasses may overwhelm the facilitative effects of hydraulic lift. Ecol. Letters 7, 623-631. 
Author-produced version of the article published in Forest Ecology and Management, 2016, 362, 89-98

The original publication is available at http://sciencedirect.com

Doi: 10.1016/j.foreco.2015.11.046

Maestre, F.T., Cortina, J., Bautista, S., 2004. Mechanisms underlying the interaction between Pinus halepensis and the native late-successional shrub Pistacia lentiscus in a semi-arid plantation. Ecography 27, 776-786.

Mediavilla, S., Escudero, A., 2010. Differences in biomass allocation patterns between saplings of two co-occurring Mediterranean oaks as reflecting different strategies in the use of light and water. Eur. J. For. Res. 129, 697-706.

Medhurst, J.L., Pinkard, E.A., Beadle, C.L., Worledge, D., 2003. Growth and stem form responses of plantation-grown Acacia melanoxylon (R. Br.) to form pruning and nurse-crop thinning. For. Ecol. Manage. 179, 183-193.

Padilla, F.M., Pugnaire, F.I., 2006. The role of nurse plants in the restoration of degraded environments. Front. Ecol. Environ. 4, 196-202.

Pages, J.P., Michalet, R., 2003. A test of the indirect facilitation model in a temperate hardwood forest of the northern French Alps. J. Ecol., 91, 932-940.

Paquette A., Messier C., 2011. The effect of biodiversity on tree productivity: from temperate to boreal forests. Global Ecology and Biogeography, 20:1708-180.

Prévosto, B., Balandier, P., 2007. Influence of nurse birch and Scots pine seedlings on early aerial development of European beech seedlings in an open-field plantation of Central France. Forestry 80, 253-264.

Prévosto, B., Monnier, Y., Ripert, C., Fernandez, C., 2011a. Can we use shelterwoods in Mediterranean pine forests to promote oak seedling development? For. Ecol. Manage. 262, 1426-1433.

Prévosto, B., Monnier, Y., Ripert, C., Fernandez, C., 2011b. Diversification of Pinus halepensis by sowing Quercus ilex and Quercus pubescens acorns: testing the effects of different vegetation and soil treatments. Eur. J. For. Res. 130, 67-76. 
Prévosto, B., Monnier, Y., Ripert, C., Fernandez, C., 2012. To what extent do time, species identity and selected plant response variables influence woody plant interactions? J. Appl. Ecol. 49, 1344-1355.

Quézel, P., Barbero, M., 1992. Le pin d'Alep et les espèces voisines: répartition et caractères écologiques généraux, sa dynamique récente en France méditerranéenne. For. Méd. 13, 158170.

Rey Benayas, J.M., Navarro, J., Espigares, T., Nicolau, J.M., Zavala, M.A., 2005. Effects of artificial shading and weed mowing in reforestation of Mediterranean abandoned cropland with contrasting Quercus species. For. Ecol. Manage. 212, 302-314.

Saha, S., Kuehne, C., Kohnle, U., Brang, P., Ehring, A., Geisel, J., Leder, B., Muth, M., Petersen, R., Peter, J., Ruhm, W., Bauhus, J., 2012. Growth and quality of young oaks (Quercus robur and Quercus petraea) grown in cluster plantings in central Europe: A weighted meta-analysis. For. Ecol. Manage. 283, 106-118.

Takenaka, A., 2000. Shoot growth responses to light microenvironment and correlative inhibition in tree seedlings under a forest canopy. Tree Physiol. 20, 987-991.

Van der Waal, C., de Kroon, H., de Boer, W.F., Heitkonig, I.M.A., Skidmore, A.K., de Knegt, H.J., et al., 2009. Water and nutrients alter herbaceous competitive effects on tree seedlings in a semi-arid savanna. J. Ecol. 97, 430-439.

Vilà, M., Vayreda, J., Comas, L., Ibañez, J.J., Mata, T., Obón, B. 2007. Species richness and wood production: a positive association in Mediterranean forests. Ecol. Letters 10, 241-250. 